\title{
Public Relations Activity to Shape Brand Awareness of Lounge and Bar in Jakarta
}

\author{
William \\ Communication Department \\ Bina Nusantara University \\ Jakarta, Indonesia \\ wilx_05@homail.com
}

\author{
La Mani \\ Communication Department \\ Bina Nusantara University \\ Jakarta, Indonesia \\ la.mani@binus.edu
}

\author{
Syahdimar Anggita \\ Communication Department \\ Bina Nusantara University \\ Jakarta, Indonesia \\ anggitashp@gmail.com
}

\begin{abstract}
The purpose of this research is to study the public relations strategies used by Jakartan bar and lounge to shape the brand awareness. The research method is qualitative descriptive that is validated by triangulation technique. Data is collected through observation and in-depth interview. Public Relations Tools is used to analyze the social media related data. The results of this research would be advantageous for bar and lounge businesses activists when developing publication, event, news, community involvement, information, lobbying, corporate social responsibility using social media to gain brand awareness. It is concluded that public relation strategies have been done by event as a top activity with social media as a priority media compared to conventional media.
\end{abstract}

Keywords: Public Relation Activity, Brand Awareness, Lounge, Bar

\section{INTRODUCTION}

Responding to intense business rivalry that is escalating throughout the days, business actors are required to create creative industry. Creative industry cannot be seen as a singular business model but as a whole process from delivering promotion to selling products and harnessing positive image through Public Relations (PR).

According to Grunig and Hunt (1962), PR has a significant, important role for organization or company. As cited from Sundstrom (2012)[1], PR is "the management of communication between an organization and its publics". Hence, PR goals means that the more message contributes to those goals, whether it increases sales, reputation or awareness, the more effective the communication has been (Radford 2011)[2].

One of the reason that drives people to establish their business is the skyrocketing demand from the market niche, be it the needs for hanging out place. The New York Times once highlighted about the cultural aspect of hanging out or nongkrong ("hanging out" as translated in Indonesian). According to the newspaper, nongkrong is something defined as doing nothing "In many ways, the convenience store's evolution was a given in a country like Indonesia, where the penchant for hanging out runs so deep that there is a word for sitting, talking and generally doing nothing.

There are various kind of places for hanging out such as bar, mini market, coffee shop and cafe. These places offer different kind of services such as various items to sell, competitive price, and another facilities supporting the hospitality.
Considering todays progress, as observed in another major cities across Indonesia, the food and entertainment industry has been growing quite rapidly. Despite urban people preference to hang out in the mall, bar has become one of the most popular alternatives. According to the data taken from the Chief of Night Entertainment Entrepreneurs Association (Asosiasi Pengusaha Hiburan Malam), today, Jakarta alone has at least 4,000 hanging out venues ranging from pool and bar, massage and spa to nightclubs and karaoke. These entertainment venues accounted for, at least, 4 trillion rupiah of tax revenue (detik.com).

Between 2015 and 2017, the proportion of nightclubs in Jakarta grew rapidly at about 40 percent, especially the number of bar that has escalated from 705 to 1172 bars. The increasing proportion of bars and nightclubs could worsen the business competition among business actors (kompas.id)[3]. The business actors are required to undertake any creative activities such as brand awareness through PR in order to succeed the business competition.

Brand is a name, term, sign, symbol or design that indicates the identity of the manufacturer of the seller of the product or service. Consumers view the brand as an important part of the product, and the establishment of a brand can add value to a product (Kotler, 2009)[4]. According to Macdonald (2000)[5], brand awareness tactic is an important choice for consumers facing a new decision task; and that subjects who are aware of one brand in a choice set to sample fewer growing niche brands across a series of product trials. Introducing the name of the company to provide corporate identity and create audiences to know their business as mentioned in Percy and Rossister Frequently overlooked in discussions of advertising strategy, yet, brand awareness is a crucial consideration. It may be thought of as a buyer's - ability to identify a brand within a category in sufficient detail to make a purchase. It is important to remember that sufficient detail does not always require identification of the brand name.

Nowadays, the existence of a weakness in terms of PR for an organization / modern company is the inability to build a harmonious relationship in all public-both internally and externally. Therefore, the authors conducted this research. This research aims to investigate the following questions, namely: (1) How PR strategy implemented by bar and lounge in Jakarta in establishing brand awareness? (2) Is there any barriers in conducting the brand awareness activities? (3) What are the recommended solutions to resolve the barriers? 


\section{RESEARCH METHODS}

This research uses qualitative descriptive method. This research aimed to describe the activity of PR in shaping brand awareness in bar and lounge businesses in Jakarta. Data were collected through observation and depth interviews from informants. Eligible informants were determined purposively, ie from three (3) bar or lounge in Jakarta, Vote Bar, Nu China and Markas Mbrio Bar. Nine informants were selected purposively from each bar or lounge representing 3 key positions, which are marketing manager, marketing PR and operational manager. The research was conducted in South Jakarta, North Jakarta and West Jakarta.

\section{RESULT}

A major element in modern marketing communication is PR. One of its functions is to create brand awareness, which is an important dimension for a company, because the company product may be bought when the interest is planted in the hearts of the costumers.

Brand awareness has multiple levels: (1) Unaware of the brand. At this stage, the customer doubts, or not sure whether they are aware of the brands or not. This level should be avoided by the company: (2) Brand Recognition. At this stage, the customer is able to identify the brands mentioned; (3) Brand Recall. At this stage, the customer is able to remember the brand without given stimulus; (4) Top of Mind. At this stage, the brand first comes to the customer mind when talking about a specific product category. Other stage is brand association that is defined as every aspects related to the brand that are memorized by the customer. Brand association contributes to various values for the company, among others: (1) Eases the customers to get information about the brand; (2) Affects customer interpretation on the facts of the brand; (3) Differentiates a brand from competitors; (4) Strengthen the brand position in the market (5) The reason for the customer to use the brand; (6) The basis for brand expansion (Kartajaya, 2010)[6].

PR activity functions and roles at a company or institution are media releases, employee newsletters, fundraising campaigns, publicity and promotion eforts, investor reports, and issue backgrounders and fact sheets (Radford, 2011)[2]. In addition, there is another activity which is known as pencils (publications, events, news, community involvement, image, lobbying, social responsibility) (Ruslan, 2013).

In association with the research on bar and lounge PR activities in Jakarta in building awareness, the results can be described as follows:

\section{A. Publication}

For company, publication has the purpose to convey information to the wider community, in other words publications are an important part in the preparation of brand awareness. Publicity and promotion are vital Public Relations functions that organizations use to interact with people who are making various choices: to gain awareness, to become informed, to be persuaded and to created meaning (Heath \& Coombs, 2001)[7].

Based on the research results, publicity carried out by PR in the bar and lounge businesses uses a variety of media, namely social media, flyering, magazines and billboards. Interestingly, according to research published by Nielsen, the bar and lounge business activists only slightly rely on conventional media, conversely, they use social media as the main platform of their publication (Lubis, 2017)[8] "The high internet usage among print media readers reaching $86 \%$, which is above average $(61 \%)$. Based on the analysis, compared to conventional media, social media is more appropriate to be utilized, because utilizing social media is more cost effective than utilizing conventional media.

\section{B. Event}

Events are essentially an assembly or reunion of people for private or public celebrations, rituals or remembrance (Glenn Mc Cartney, 2010)[9]. Events can take various forms, including incentive / reward programs, product launches, open days, conferences, product sampling, publicity events, the socalled 'created' events, road shows, press conferences, competitions / contests, exhibitions, corporate entertainment, charity fundraisers, trade shows and product visitor attractions (Wood, 2009)[10].

Speaking of events, there are also event calendars or routine events, special events, and event momentum which are the benchmark in this study. Examples of common event calendar in bars and lounges businesses in Jakarta are Halloween, Christmas, Chinese New Year and other regular events that are conducted every week or incidental events aligning with the growing issue in the community.

Other event activities are special events. It is a specific activity conducted aside from the routine ones. A special event is a one-time or rarely occurring event apart of the normal program or activities of the sponsoring or organizing body. To a customer or guest, a special event is an opportunity for leisure, social, or cultural experience outside the normal range of choices or beyond everyday experience (J Allen, 2002)[11]. In addition, planned events are spatially temporal phenomena and are unique because of the interactions among the settings, people, and management systems including design elements and the program (Getz, 2008)[12].

Results of the primary and secondary data state that bars and lounges businesses in Jakarta carry out events such as venue launching, special events employing Event Organizer (EO) by performing DJs or singers. Thus, bars and lounges businesses in Jakarta conducted the special events by highlighting their artists.

Next is the momentum event. It is a more specific event and takes certain moments, usually to celebrate special moments carried out by the company such as the company's anniversary, silver anniversary, golden anniversary, diamond anniversary celebration, and even welcoming the millennium (Ruslan, 2013). According to the interview results, momentum events are mostly initiated to launch EO or various products which are usually held every three months.

The primary and secondary data collection results indicate that the average age of visitors are under 25 years old, who have not been too focused on the activities, in the sense that the visitors have not yet engage within the moment for example when they celebrate birthdays every year.

It is undeniable that the existence of bar and lounge activities in Jakarta such as DJ events, product launching, anniversary and events arranged by EO is one of the strategic methods in generating brand awareness that is reinforced by 
the following statement: "Event marketing has been viewed as valuable in generating awareness for the brand and corporate images, but only few have studied its ability to communicate a more sophisticated, specific message or contribution to other aspects of brand equity. The conclusion is that events impact on brand equity both directly and indirectly through brand experience and, for some events, through brand attitude" (Schmitt, 2015)[13].

\section{News}

PR is Who They are tacticians and technicians who design and craft communication tools such as media releases (Radford, 2011)[2]. News is an activity for companies to convey information. A PR must have the ability to write for publicity purposes. News articles have influenced the participants' judgment of public opinion on these issues significantly, event when adjusted for effect projected personal opinion (Gunther, 1995)[14]. The interview quoted "a kind of Indoclubbing events, such as Java Party, and we worked with Juice magazine, that's all."

Based on the study results, social media is the most-used media to convey information, but the bar and lounge businesses also often uses local media, namely the local community/district media. The use of social media can be observed from their collaboration with many online media such as Java Party, Indoclubing, Jakarta Clubbing and others, where the media is more focused on carrying out their activities on Instagram and Path. Administrators have been assigned to specifically handle the social media platforms used by each bar and lounge in Jakarta. PR on journalistic content will be useful to determine what factors are associated with specific types of influence (Magdalena Obermaier, 2015)[15]. It is expected that the news carried out by PR can influence the wider community, in the sense that the message can reach the community in accordance with the purpose of the PR themselves. It can be observed that collaboration with social media is more intense than that to conventional media such as collaboration with Juice magazine that was only conducted in a few times and unfortunately the collaboration did not reach either television or radio. It is known that the information contained in the PR material is more contextual in the broadcast rather than that contained in print media (Justin Lewis, 2008)[16].

\section{Community Involvement}

Building relationship with the community or an organization may support the corporation position in the community. The principle is, the more people involved, the better the result will be (Marinetto, 2003)[17]. Community involvement $(\mathrm{CI})$ is now regarded as integral to good practice inpolicy circles, meaning that CI has significant role in decision making process or supporting the development of a corporation.

These views suggest that external pressures on companies may both influence decisions regarding managerial structures within which CI is managed and the nature of those involvement activities in such a way that we may expect to observe systematic patterns in administrative structure and patterns in the relationship between structure and Company Community Involvement (CCI) activities. However, in the next section we argue that the preferences of broad societal stakeholders may play a significant role in shaping CCI activity. To the extent that CCI activities reflect the preferences of society we ought to observe regularities in patterns of CCI activity (Brammer, 2003)[18].

Public Relations (PR) work by building relationship with the community and organization, especially motorbike and car communities, vape community and also university students community. Reginald A. Litz (2008)[19] argues that the buying group's influence may be greatest when the members are newest to the group and that, over time, members gradually adjust their activity levels to a more appropriate and firm-specific level. Community is one of the important aspects of the corporation because community builds communication among new members. A generally positive perception of offshore renewables as providing a range of benefits, rather than negative impacts, for communities can influence the framing of benefits as being about spreading the advantages of national resources (Rudolph, 2017)[20], beside that, community engagement is one aspect of the E-won. Community can influence people (Robert allen king, 2014)[21] such as building brand awarness and shaping people perceptions about certain places, namely Community of Bar and Lounge in Jakarta.

\section{E. Inform or Image}

Inform or image is an action that leads to build public's perception towards the company. Inform or image has two functions: provide information to public and catch public attention, so that positive image can be generated (Ruslan, 2013).

Bar and Lounge community in Jakarta tends to create events with different concepts. They want to build image as a venue providing attractive events. In marketing, consumers are assumed to hold an image of products and organizations determined by factors such as the physical characteristics, packaging, advertising, and price. (Alexander Josiassen, 2015)[22].

\section{F. Lobbying and Negotiation}

Lobbying is one of effective public relation activities in gaining support or achieving goals, where financial supports, and also other supports such as promotions, are required. Persuading done by a pressure group to gain profit is called lobbying. The person who makes a pressure to someone is called a lobbyist. Lobbying to get social or economic support (Fujita, 2016)[23]. Lobbying activity of bar and lounge community is targeting cigarette and alcoholic drinks to gain financial support, such as fund and products that will be used it for the event. Accepting sponsorship is one tool (negotiation) in this strategy (Berder, 1991)[24].

It was found that Lobbying Activities carried out by Bars and Lounges in Jakarta to rise a fund to support the events they did. Lobbying or negotiation activities are also carried out for the event activities itself or providing support for the event activities.

\section{G. Corporate Social Responsibility}

One of the aspects influencing the corporation sustainability is the support from the community, at least the support from the surrounding communities. Sometimes, venues selling liquors / alchoholic drinks worries the community. Most notably, we found that a high consumers 
assumed that CSR activities were motivated by imagepromotional goals under all conditions that could overcome backfire effects even when the company had a bad reputation, the benefit salience was high, and consumers learned about the corporate social responsibility (CSR) activity from a company source (Yeosun Yoon, 2006)[25].

Charity event targeted nearby communities during disaster event, such as flood. Additionally, during Ramadhan, charity event in the form of providing snacks and dinner for the break fasting may be useful in gaining support from communities around the corporation.

Besides that, CSR has positive impact on the corporation's image, such as using CSR policies as instruments for managing consumer perceptions of a company (Swaen, 2008). They constitute communication tools that help to increase its trust capital. CSR activities will increase the number of loyal consumers and shape positive perception through the charity event delivered in entertaining manners.

\section{H. Social Media}

Social media is an Internet based platform that helps the users to interact and present themselves, either live or recorded, to a certain group of people or a large number of people leading to user-generated content and interactive perception with others (Hayes, 2014)[26]

The five purposes of social media in health promotion highlighted in this article (market insights, establish a brand and create brand awareness, disseminate critical information, expand reach to more diverse audiences, and foster public engagement and partnerships) (Neiger, 2012)[27].

Khim-Yong Goh (2013)[28] reveals that contents from mass media or social media are evaluative and can serve to persuade consumers. In 2017, about 143 million out of 262 million Indonesian actively used social media (Bohang, 2018)[29]. Social media, such as Instagram, used by corporations to display their activities. They also use e-flyer to promote an event, build partnership with e-media such as Java Party, indoclubing.com and dancesignal.com. Based on the interview and observation to the three Bars $(\mathrm{Nu}$ China, Vote Bar, and Markas Mbrio), it is confirmed that bar and lounge in Jakarta employ social media staff. Based on the results of interviews and observations to the three bars conducted by researchers, it was also obtained the data that each of the bars and lounges in Jakarta has special admin to manage social media so that bars and lounges in Jakarta can get feedback from their social media followers about the successful promotion activities that has been carried out. It can be concluded that social media for bars and lounges in Jakarta is one of the most important tools for their success.

\section{CONCLUSION}

Most of the events created by Bar and Lounge PR personnel in Jakarta are publication, such as distributing flyers, set up big billboard, and place advertisement in the magazine to promote the venue. They also promote upcoming events and review of the past events in that media. The content of the news tends to create news about their events, launching new products, and partnership with singers launching their new single.

From the CI aspect, it indicates that partnerships with the automotive, vape, and university students communities are profitable. Lobbying and negotiation activities in cigarette and alcoholic drinks corporations are categorized as fundraising activity to provide financial support fo the upcoming events. On the other hand, CSR is commonly delivered as charity, such as Charity Night event. Social media is mainly utilized to promote upcoming events and products, for instance beverages, food, and interior appearance.

To conclude, PR personnel in Bar and Lounge in Jakarta focus on shaping the brand awareness. They tend to use event as promotion tool to attract consumers, introducing their venues, and build public perception that the venues offers attractive events.

\section{REFERENCES}

[1] B. Sundstrom, "No Title," Integr. Public Relations, 2012.

[2] G. P. Radford, "No Title," Public relations a Postmod. world, 2011.

[3] p. r luhur arsiyanto putra, "No Title," jumlah tempat hiburan jkarta naik hampir 40 persen, 2017. [Online]. Available: kompas.id.

[4] P. K. Kotler, "No Title," Manaj. Pemasar., 2009.

[5] B. M. Emma K. Macdonald, "No Title," Brand Aware. Eff. Consum. Decis. Mak. a Common, Repeat Purch. Prod. A Replication, 2000.

[6] H. Kartajaya, "No Title," Brand Oper. jakarta Esensi Erlangga Gr., 2010.

[7] T. W. heath, L. R., \& Coombs, "No Title," Today's Public Relations An Introd. London Sage Publ. LTD, 2001.

[8] m Lubis, "No Title," 2017. [Online]. Available: http://www.nielsen.com/id/en/pressroom/2017/MEDIA-CETAK-MAMPUMEMPERTAHANKAN-POSISINYA.html.

[9] g. M. Cartney, "No Title," event Manag., 2010.

[10] E. Wood, "No Title," Eval. event Mark. Exp. or outcome? J. Promot., 2009.

[11] O. W. J Allen, "No Title," Festiv. Spec. Event Manag., 2002.

[12] D. Getz, "No Title," Event Tour. Defin. Evol. Res. 2008.

[13] L. Z. Schmitt, "No Title," impact event Mark. Brand equity, 2015.

[14] A. C. GUNTHER, "No Title," Persuas. Press Inference Eff. Mass Media Perceived public Opin., 1995.

[15] T. K. Magdalena Obermaier, "No Title," Deep Impact? How Journalists Perceive Influ. Public Relations TheirNews Cover. WhichVariables Determ. This impact, 2015.

[16] A. W. Justin Lewis, "No Title," A COMPROMISED FOURTH ESTATE, 2008.

[17] M. Marinetto, "No Title," Who Wants to be an Act. Citizen? Polit. Pract. Community ivolvement, 2003.

[18] A. M. Stephen Brammer, "No Title," Eff. StakeholderPreferences, Organ. Struct. Ind. Type Corp. Community Involv., 2003.

[19] S. S. Reginald A. Litz, "No Title," Altruistic by Assoc. Buy. Groups Small, 2008.

[20] C. H. David Rudolph, "No Title," Community 
benefits from offshore renewablesThe Relatsh. between Differ. understandings impact,community, benefit, 2017.

[21] p. r Robert allen king, "No Title," we know don't know about online Word-of-Mouth A Rev. Synth. Lit., 2014.

[22] A. G. Alexander Josiassen, "No Title," ImageryImage Duality Model An Integr. Rev. Advocating Improv. Delimitation Concepts, 2015.

[23] T. M. Rieko Fujita, "No Title," Lobbying Simul. Issues Soc. Sci., 2016.

[24] S. Berder, "No Title," Act. versus Negot. Strateg. Environ. Mov., 1991.

[25] Z. G.-C. Yeosun Yoon, "No Title," Eff. Corp. Soc.
Responsib. (CSR)Activities Co. With Bad Reputations, 2006.

[26] C. T. Hayes, "No Title," Soc. Media Defin. Dev. Divining, 2014.

[27] R. T. Brad L. Neiger, "No Title," Use Soc. Media Heal. Promot. Purp. Key Perform. Indic. Eval. Metrics, 2012.

[28] C.-S. H. Khim-Yong Goh, "No Title," Soc. Media Brand Community, 2013.

[29] F. K. Bohang, "No Title," 2018. [Online]. Available:

https://tekno.kompas.com/read/2018/02/22/1645317 7/berapa-jumlah-pengguna-internet-indonesia. [Accessed: 22-Feb-2018]. 